\title{
BEVEZETŐ \\ A HATÉKONY PEDAGóguSOK ROVATHOZ
}

A mostani lapszámban a Hatékony pedagógusok rovatunkban két írással jelentkezünk. Mind szerzőik, mind a megidézett pedagógusok nagyon különbözőek. Egymás mellé kerülésük véletlenszerü. Ám, ha figyelmesen olvassuk a visszaemlékezéseket, mégis feltünik néhány hasonlóság. Nem azokra a - némiképp külsődleges - elemekre gondolok, amelyek mindkét párost jellemezték: nem gyerekként találkoztak, a pedagógusok viszont kisgyermekekkel foglalkoztak, a visszaemlékezőknek is szoros közük van a tanítói professzióhoz. Bár ezek vitathatatlan tények, de a hatás szempontjából nem lényegiek. A „titok” megfejtéséhez talán közelebb visz, hogy mindketten örömröl, boldogságról írnak. Ezeknél a pedagógusoknál boldogok voltak a gyerekek, öröm volt tanulni, együtt lenni; a tanítók örömforrásként élték át napi munkájukat, $\mathrm{s}$ visszatekintve ma is - már az összegzés, elmélkedés periódusában élve vagy éppen más foglalkozást űzve - ezt a szeretett munkából fakadó megelégedettséget, mondhatjuk talán, boldogságot sugározzák. Így váltak etalonná, viszonyítási ponttá fiatal kollégáik számára, akik - mint írják - gyakran mérik magukat hozzájuk. S gyakran élik át, hogy mindig van mit tanulniuk tőlük.

(a szerkesztö) 